Archives of Agriculture and Environmental Science

\title{
Determination of seeding rate and inter row spacing on the yield of tef (Eragrostis tef Zucc. Trotter) in the dryland areas of Wag Lasta, North Eastern Amhara, Ethiopia
}

\section{Alemu Lakew* and Tafere Berhanu}

Amhara Regional Agricultural Research Institute (ARARI), Sekota Dry Land Agricultural Research Center, P.O. Box, 62, Sekota, ETHIOPIA

"Corresponding author's E-mail: alemubelewu@gmail.com

\section{ARTICLE HISTORY}

Received: 11 December 2018

Revised received: 10 February 2019

Accepted: 20 February 2019

\section{Keywords}

Dryland areas

Eragrostis tef

Ethiopia

Inter row spacing

Seeding rate

\begin{abstract}
Tef production and productivity in Wag lasta is very low as compared to the national average due to many production constraints, including use of inappropriate agronomic practices and low yielder varieties. Therefore, an experiment was conducted to optimize seeding rate and inter-row spacing of tef in the study areas of Wag-Lasta in 2013 and 2014 cropping season. Five seeding rates $\left(5,10,15,20\right.$ and $\left.25 \mathrm{~kg} \mathrm{ha}^{-1}\right)$ and three inter row spacing's $(15,20,25 \mathrm{~cm})$ were laid out in a factorial RCBD with three replications. An additional plot of broad cast of tef seed with $25 \mathrm{~kg} / \mathrm{ha}$ as a satellite control was included and making a total of 16 treatments. Grain yield showed significance difference at Woleh 2014 on both seeding rate and inter row spacing and combined analysis by location for the year 2014 cropping season for the factor seeding rate. At Lalibela, grain yield and other agronomic traits did not show a significance difference except days to heading, in case of inter row spacing in 2013 and number of tillers in case of seeding rate in 2014 cropping seasons. Based on the combined analysis result the highest grain yield was recorded from $15 \mathrm{~kg} / \mathrm{ha}$ seeding rate with $20 \mathrm{~cm}$ inter row spacing. Generally sowing of tef with the rate of $15 \mathrm{~kg} \mathrm{ha}^{-1}$ and $20 \mathrm{~cm}$ inter row spacing is effective in attaining higher grain yield and economic benefit.
\end{abstract}

(C)2019 Agriculture and Environmental Science Academy

Citation of this article: Lakew, A. and Berhanu, T. (2019). Determination of seeding rate and inter row spacing on the yield of tef (Eragrostis tef Zucc. Trotter) in the dryland areas of Wag Lasta, North Eastern Amhara, Ethiopia. Archives of Agriculture and Environmental Science, 4(1): 69-74, https://dx.doi.org/10.26832/24566632.2019.0401011

\section{INTRODUCTION}

Teff [Eragrostistef (Zucc.) Trotter] is an allotetraploid $(2 n=4 x=40)$ crop belonging to the grass family poaceae and it is among the major cereals of Ethiopia (Paff and Asseng, 2018). It has the largest value in terms of both production and consumption in Ethiopia (Minten et al., 2013; Tesfay and Gebresamuel. 2016). Tef in Ethiopia stands first in area coverage and second in total annual production next to maize, and ranks the lowest yield compared with other cereals grown in Ethiopia (CSA, 2016; Assefa et al., 2017; Tesfahun, 2018).

It is the major staple cereal crops and highly adapted to diverse agro-ecological zones including conditions marginal to the production of most of the other crops (Hailu and Seyfu, 2001). It is used for making injera, which is a staple and popular food in the national diet of Ethiopian (Debebe, 2005). When grown as a cereal, farmers highly value its straw as source of animals feed, especially during the dry season (Cheng et al., 2017). Tef straw, besides being the most appreciated feed for cattle, it is also used to reinforce mud and plaster the walls of tukuls and local grain storage facilities called gottera (Ketema, 1997; Tesfahun, 2018). Similarly, tef is one of cereal crops, which is produced in many small holder farmers in Wag himra, North wollo as well as in Amhara region. Tef in Wag Himra Administration Zone and in north Wollo stands first in area coverage and second in total annual production next to sorghum. The average productivity of tef in Wag-himra and North Wollo is $8.25 \mathrm{qt} / \mathrm{ha}$ and $10.41 \mathrm{qt} / \mathrm{ha}$ respectively, while the national tef productivity is 15.6 qt /ha 
(CSA, 2016; Tesfay and Gebresamuel, 2016).

In spite of its tremendous importance, tef production in the country as well as in the region particularly in Wag Lasta has faced immense production constraints affecting its yield potential. This is because of agronomic constraints that include lodging, low modern input utilization, and high post-harvest losses and sowing method, and also farmers are used low yielding local varieties, using of high seed rate and terminal moisture deficits are the major once (Tsegay et al., 2015; Wubante and Menzir, 2017).

Seed rate is the most important agronomic aspect which needs due attention. According to Amhara national state agricultural bureau Dryland crop production package (2015) has recommend $20 \mathrm{~cm}$ row spacing with $2-3 \mathrm{~kg} / \mathrm{ha}$ seeding rate for tef production of throughout the region. According to Wubante and Menzir (2017), when the plant density exceeds an optimum level, competition among plants for light above ground, water and nutrients below ground becomes severe. Consequently, plant growth slows down and the grain yield decreases. Melaku (2008) explains that there was significance difference increase in yield components of tef with decreasing seed rate from highest to lowest. On the other hand, the lodging percentage of the crop was increased by increasing the seed rate. It is, hence, necessary to determine the optimum density of plant population per unit area to obtain maximum yields (Tsegay et al., 2015).

Most farmers practice the traditional sowing method of broad casting the seed at a rate of 25-30 kg ha ${ }^{-1}$, which creates excess crop density and increases competition among plants for nutrients, water, sunlight and $\mathrm{CO}_{2}$. More over broadcasting methods requires additional seed rate compared to row sowing method thus increases cost of production (Cheng et al., 2017). Furthermore, broadcasting results lodging; which is the main cause for low yield of tef due to high plant density. Row planting in tef is reported to have better yielding advantage over broadcast planting. To minimize the problem of lodging on tef, low seed rate, row planting, late sowing and application of plant growth regulators were used (Hundera et al., 2001; Tesfahunegn et al., 2015).

In the Amhara region in general and in wag lasta in particular farmers practice broad casting methods of sowing Hence, this research was initiated to optimize seeding rate and inter-row spacing of tef in the study areas of Wag-Lasta.

\section{MATERIALS AND METHODS}

\section{Experimental design}

The experiment was conducted on the black soils of Lalibela and Woleh testing sites of Sekota dryland agricultural research centre in Eastern Amhara region, Ethiopia during the main cropping seasons for two consecutive years (2013 and 2014). Lalibela testing site has been characterized by an altitude ranging from 2200 to 2600 m.a.s.l, minimum and maximum temperatures of $12^{\circ} \mathrm{C}$ and $28.8^{\circ} \mathrm{C}$ and an average annual rainfall of 500 to $1000 \mathrm{~mm}$ with latitude of $12^{\prime} \mathrm{N}$ and $39.03 \mathrm{E}$ ', whereas Woleh testing site also characterized as an altitude of 2000 m.a.s.l, minimum and maximum temperatures of $14^{\circ} \mathrm{C}$ and $26^{\circ} \mathrm{C}$ and an average annual rainfall of 500 to $700 \mathrm{~mm}$ with latitude of $12.65{ }^{\prime} \mathrm{N}$ ' and with longitude of 39.03 ' $\mathrm{E}$. The treatments considered of five seed rates $\left(5,10,15,20,25 \mathrm{~kg} \mathrm{ha}^{-1}\right)$ and three row spaces (15, 20 and $25 \mathrm{~cm}$ ).

One additional plot of broadcast of tef seed at $25 \mathrm{~kg}$ ha- 1 was considered as a standard check and making a total of sixteen treatments. The Randomized Complete Block Design factorial arrangement with three replications of plot size of $5 \mathrm{~m} \times 3 \mathrm{~m}$ was used (Tsegay et al., 2015). Blanket recommendations of Urea and DAP fertilizer (50 kg/ha and $100 \mathrm{~kg} / \mathrm{ha}$ ) were used as the source of $\mathrm{N}$ and $\mathrm{P}$, respectively.

\section{Cultivation conditions and data collection}

The crop was sown at on sate of rain fall half of July when the field capacity of the soil is arrived. Application of urea was in two split, while the entire rate of phosphorus was applied at sowing in band. The experimental sites were prepared well. Each plot and block were separated by $0.50 \mathrm{~m}$ and $1.5 \mathrm{~m}$, respectively. Tef variety Kuncho ( $\mathrm{Dz} \mathrm{Cr}$-387) was used as a testing crop for the experiment. Important agronomic practices like land preparation and weeding were uniformly applied to all experimental plots as often as required (Tesfahunegn et al., 2015; Tesfay and Gebresamuel, 2016).

Plant height at maturity $(\mathrm{cm})$, number of tillers and number of effective tillers per plant, lodging (\%), grain and biomass yield $(\mathrm{kg} / \mathrm{ha})$ were collected as growth and yield parameters of tef, then finally purified and arranged for further analysis (Tesfahunegn et al., 2015; Tesfahun, 2018).

\section{Partial budget analysis}

The partial budget analysis was calculated to compare gain and losses between one treatment and another (Abraha et al., 2017). It was done based on the following methodology prescribed by CIMMYT (1988). It was considered the analysis of gross benefit (GB), total variable cost (TVC) and the net benefit (NB).

\section{$\mathrm{G} \cdot \mathrm{B}=(\mathrm{YAXPA})+(\mathrm{YBXPB})$}

TVC $=$ (The sum of all the costs which vary between treatments. $\mathrm{NB}=\mathrm{GB}-\mathrm{TVC}$

Where,

CIMMIT=International Maize and Wheat improvement center $\mathrm{G} . \mathrm{B}=$ Grose Benefit, NB=Net Benefit, $Y A=$ Grain Yield, $\mathrm{PA}=$ Price per unit of quintal of grain, $\mathrm{YB}=$ Straw yield and $\mathrm{PB}=$ Price of straw per quintal (Shekim).

\section{Statistical analysis}

The analysis of variance (ANOVA) was carried out following statistical procedures appropriate for the experimental design using statistical analysis system (SAS) program package version 9.0 (SAS, 2002). Whenever treatment effects were significant at 0.01 or 0.05 level of significance, the means were separated by using the Duncan multiple range test (DMRT) procedures at 0.05 probability level of significance. 


\section{RESULTS AND DISCUSSION}

\section{Grain and biomass yield}

Grain yield was significantly $(P<0.05)$ affected by different seeding rate and inter row spacing at Woleh in the year 2014. The highest grain yield (1617 and $1705 \mathrm{~kg} / \mathrm{ha}$ ) was recorded from $20 \mathrm{~cm}$ inter row spacing and $15 \mathrm{~kg} /$ ha seeding rate respectively whereas the lowest grain yield ( $1293 \mathrm{~kg} / \mathrm{ha}$ ) was recorded from broad casting sowing methods with a seed rate of $25 \mathrm{~kg} / \mathrm{ha}$ at Woleh (Table 1). Similar result was reported by Getahun et al. (2018), who found that higher grain yield was obtained from $20 \mathrm{~cm}$ inter row spacing with 10 and $15 \mathrm{~kg} / \mathrm{ha}$ seeding rates and lowest grain yield was recorded from broad casting sowing methods with $25 \mathrm{~kg} / \mathrm{ha}$ seeding rates (Paff and Asseng, 2018).
Whereas biomass yield and panicle length showed significance difference by seeding rates, but did not showed significance difference by inter row spacing's. The highest biomass yield $(6844 \mathrm{~kg} / \mathrm{ha}$ ) was recorded from $25 \mathrm{~kg} /$ ha seeding rates broad casting seeding methods, whereas the lowest biomass yield was recorded from $20 \mathrm{~cm}$ inter row spacing's at Woleh location in 2014 cropping seasons while days to heading, days to maturity, number of tilers, number of effective tillers, plant height and lodging percentage didn't show any significant difference in both main effects of inter row spacing and seeding rates as well as their interactions at Woleh in 2014. The current result not in line with Bekalu and Arega (2016) who found that higher biomass yield was recorded from $5 \mathrm{~kg} / \mathrm{ha}$ seeding rats than 10 , 20 and $25 \mathrm{~kg} /$ ha seeding rates.

Table 1. Effects of seeding rate and inter row spacing on grain yield and other agronomic parameters of tef at Woleh in 2014 cropping season.

\begin{tabular}{|c|c|c|c|c|c|c|c|c|c|}
\hline \multirow{2}{*}{ Factor } & \multicolumn{9}{|c|}{ Parameters } \\
\hline & $\mathrm{DH}$ & DM & NT & NET & PL & $\mathrm{PH}$ & LDG & $\mathrm{BM}(\mathrm{Qt})$ & GY(Qt) \\
\hline \multicolumn{10}{|c|}{ Row spacing } \\
\hline 15 & 53.30 & 80 & 5.21 & 4.06 & 40.28 & 116.12 & 58 & 61.37 & $15.15^{\mathrm{ab}}$ \\
\hline 20 & 52.00 & 81 & 4.40 & 3.64 & 38.90 & 117.00 & 57 & 60.57 & $1617^{a}$ \\
\hline 25 & 52.93 & 80 & 5.72 & 4.60 & 40.37 & 116.00 & 65 & 64.57 & $13.92^{\mathrm{ab}}$ \\
\hline Local control & 53.00 & 79 & 5.33 & 4.00 & 35.06 & 110.93 & 71 & 68.44 & $12.93^{b}$ \\
\hline $\mathrm{CV}$ & 2.39 & 2.44 & 14.9 & 25.43 & 7.93 & 5.76 & 10 & 10 & 14 \\
\hline Duncan at $5 \%$ & NS & NS & NS & NS & NS & NS & NS & NS & $*$ \\
\hline \multicolumn{10}{|c|}{ Seed rate } \\
\hline 5 & 53.77 & 81.11 & 5.13 & 4.02 & $43.62^{a}$ & 117.77 & 58.88 & $62.51 .9^{a}$ & $13.97^{\text {ba }}$ \\
\hline 10 & 52.22 & 81.00 & 5.60 & 4.55 & $39.68^{b}$ & 117.70 & 61.11 & $61.55 .6^{\mathrm{ab}}$ & $15.17^{\mathrm{ab}}$ \\
\hline 15 & 52.66 & 79.77 & 5.31 & 4.02 & $38.42^{b c}$ & 114.80 & 62.22 & $6259.3^{\mathrm{ab}}$ & $17.05^{a}$ \\
\hline 20 & 52.88 & 81.44 & 6.04 & 4.80 & $39.53^{b}$ & 114.53 & 51.66 & $56.88 .9^{b}$ & $15.63^{b}$ \\
\hline 25 & 53.22 & 79.66 & 5.24 & 4.37 & $39.22^{b}$ & 116.68 & 67.55 & $67.33 .0^{a}$ & $13.59^{\mathrm{ab}}$ \\
\hline Local control & 53.00 & 79.00 & 5.33 & 4.00 & $39.22^{b}$ & 110.93 & 71.66 & $68.44^{a}$ & $12.93^{b}$ \\
\hline Duncal at $5 \%$ & NS & NS & NS & NS & * & NS & NS & * & $*$ \\
\hline
\end{tabular}

Where, $\mathrm{DH}=$ Days to heading, $\mathrm{DM}=$ Days to maturity, $\mathrm{PH}=$ Plant height, $\mathrm{NT}=$ Number of tillers per plant, NET, Number of effective tiller $\mathrm{PL}=$ panicle length BMY = Bio-mass, and , GY=Grain yield. And NS, Non significance, ${ }^{*}$ statistically Significant and ${ }^{* *}$ statistically Highly significant.

Table 2. Effects of seeding rate and inter row spacing on grain yield and other agronomic parameters of tef at Lalibela in 2013 cropping season.

\begin{tabular}{|c|c|c|c|c|c|c|c|c|c|}
\hline \multirow{2}{*}{ Factor } & \multicolumn{9}{|c|}{ Parameters } \\
\hline & DAH & DAM & NT & NET & PL & $\mathrm{PH}$ & LDG & $\mathrm{BM}(\mathrm{Qt})$ & $\mathrm{GY}(\mathrm{Qt})$ \\
\hline \multicolumn{10}{|c|}{ Row spacing } \\
\hline 15 & $53^{a}$ & 98 & 1.81 & 1.81 & 38.73 & 112.33 & 58.33 & 85.60 & 16.71 \\
\hline 20 & $52^{b}$ & 97 & 1.65 & 1.65 & 39.77 & 116.13 & 54.53 & 82.40 & 16.22 \\
\hline 25 & $52^{\mathrm{bc}}$ & 98 & 1.71 & 1.71 & 37.88 & 114.13 & 52.66 & 77.95 & 14.48 \\
\hline Local control & $52^{c}$ & 97 & 1.27 & 1.27 & 43.66 & 106.66 & 58 & 92.44 & 16.66 \\
\hline $\mathrm{CV}$ & 0.84 & 0.81 & 18.84 & 18.84 & 10.17 & 5.86 & 10.3 & 12.12 & 28.18 \\
\hline Duncan at 5\% & * & NS & NS & NS & NS & NS & NS & NS & NS \\
\hline \multicolumn{10}{|c|}{ Seed rate } \\
\hline 5 & 52.00 & 98 & 1.95 & 1.98 & 39.62 & 118.44 & $53.88^{b}$ & 81.92 & 14.14 \\
\hline 10 & 53.00 & 97 & 1.52 & 1.52 & 38.64 & 114.44 & $62.72^{\mathrm{a}}$ & 79.11 & 16.00 \\
\hline 15 & 53.00 & 98 & 1.69 & 1.69 & 40.80 & 110.88 & $51.44^{b}$ & 82.22 & 17.72 \\
\hline 20 & 53.00 & 98 & 1.80 & 1.80 & 37.00 & 110.88 & $53.88^{b}$ & 78.96 & 16.00 \\
\hline 25 & 52.72 & 98 & 1.63 & 1.63 & 37.75 & 116.33 & $53.85^{b}$ & 87.70 & 15.11 \\
\hline Local control & 52.33 & 97 & 1.27 & 1.22 & 43.66 & 106.33 & $58^{\mathrm{AB}}$ & 92.44 & 16.66 \\
\hline Duncal at $5 \%$ & NS & NS & NS & NS & NS & NS & $*$ & NS & NS \\
\hline
\end{tabular}

Where, $\mathrm{DH}=$ Days to heading, $\mathrm{DM}=$ Days to maturity, $\mathrm{PH}=$ Plant height, NT=Number of tillers per plant, NET, Number of effective tiller HL=Head length BMY = Bio-mass, and , GY=Grain yield. and NS, Non significance, ${ }^{*}$ statistically Significant and ${ }^{* *}$ statistically Highly significance. 
Table 3. Effects of seeding rate and inter row spacing on grain yield and other agronomic parameters of tef at Lalibela in 2014 cropping season.

\begin{tabular}{|c|c|c|c|c|c|c|c|c|c|}
\hline \multirow{2}{*}{ Factors } & \multicolumn{9}{|c|}{ Parameters } \\
\hline & DAH & DAM & NT & NET & PL & $\mathrm{PH}$ & LDG & $\mathrm{BM}(\mathrm{Qt})$ & $G Y(Q t)$ \\
\hline \multicolumn{10}{|c|}{ Row spacing } \\
\hline 15 & 48 & 94 & 2.00 & 1.22 & 43.36 & 197.00 & 8.40 & 75.02 & 18.75 \\
\hline 20 & 48 & 94 & 1.94 & 1.22 & 43.00 & 192.00 & 8.50 & 73.53 & 18.41 \\
\hline 25 & 48 & 94 & 2.05 & 1.26 & 44.00 & 199.00 & 8.10 & 77.68 & 18.93 \\
\hline Local control & 48 & 94 & 2.19 & 1.40 & 46.33 & 206.00 & 7.20 & 80.44 & 19.91 \\
\hline Means & 48 & 94 & 2.00 & 1.24 & 43.73 & 196.72 & 76.77 & 75.72 & 18.54 \\
\hline CV & 0.79 & 0.92 & 9.79 & 13.2 & 25.21 & 5.57 & 7.56 & 8.20 & 7.89 \\
\hline Duncan at $5 \%$ & NS & NS & NS & NS & NS & NS & NS & NS & NS \\
\hline \multicolumn{10}{|c|}{ Seed rate } \\
\hline 5 & 48 & 94 & $1.99^{\mathrm{ab}}$ & 1.22 & 43.35 & 196.81 & 76.11 & 75.59 & 18.82 \\
\hline 10 & 48 & 94 & $1.99^{\mathrm{ab}}$ & 1.21 & 43.60 & 197.03 & 76.11 & 74.88 & 18.50 \\
\hline 15 & 48 & 94 & $2.05^{\mathrm{ab}}$ & 1.2 & 44.04 & 198.51 & 78.8 & 75.59 & 18.44 \\
\hline 20 & 48 & 94 & $1.8^{2 \mathrm{~b}}$ & 1.15 & 41.66 & 186.57 & 72.22 & 71.11 & 17.56 \\
\hline 25 & 48 & 94 & $2.14^{\mathrm{ab}}$ & 1.32 & 45.15 & 201.47 & 79.44 & 79.70 & 19.65 \\
\hline Local control & 48 & 94 & $2.19^{a}$ & 1.40 & 46.33 & 206.33 & 80 & 8044 & 19.91 \\
\hline Duncal at $5 \%$ & NS & NS & * & NS & NS & NS & NS & NS & NS \\
\hline
\end{tabular}

Where, $\mathrm{DH}=$ Days to heading, $\mathrm{DM}=$ Days to maturity, $\mathrm{PH}=$ Plant height, $\mathrm{NT}=$ Number of tillers per plant, NET ,Number of effective tiller HL=Head length BMY = Bio-mass, and , GY=Grain yield. And NS, Non significance, ${ }^{*}$ statistically Significant and ${ }^{* *}$ statistically Highly significance.

Table 4. Grain yield and other agronomic parameters of tef as affected by seeding rate and inter row spacing combined by year at Lalibela (2013 and 2014).

\begin{tabular}{|c|c|c|c|c|c|c|c|c|c|}
\hline \multirow{2}{*}{ Factor } & \multicolumn{9}{|c|}{ Parameters } \\
\hline & $\mathrm{DH}$ & $\mathrm{DM}$ & NT & NET & $\mathrm{PL}$ & $\mathrm{PH}$ & LDG & BMY(Qt) & GY(Qt) \\
\hline \multicolumn{10}{|c|}{ Row spacing } \\
\hline 15 & $50.80^{a}$ & 96.23 & 2.73 & 2.33 & 41.04 & 154.67 & 67.66 & 80.31 & 17.44 \\
\hline 20 & $50.43^{\mathrm{ab}}$ & 95.83 & 2.40 & 2.04 & 41.40 & 154.13 & 64.60 & 77.96 & 17.31 \\
\hline 25 & $50.32^{b}$ & 95.96 & 2.56 & 2.17 & 40.81 & 155.96 & 65.17 & 76.09 & 16.20 \\
\hline Local control & $50.16^{a b}$ & 95.83 & 1.92 & 1.53 & 45.00 & 156.49 & 64.6 & 86.44 & 16.02 \\
\hline Means & 50 & 96 & 2.52 & 2.14 & 41.00 & 155 & 66 & 78.69 & 17.09 \\
\hline $\mathrm{CV}$ & 1 & 0.61 & 35 & 41 & 8 & 6.3 & 11 & 10 & 18 \\
\hline Duncan at $5 \%$ & $*$ & NS & NS & NS & NS & NS & NS & NS & NS \\
\hline \multicolumn{10}{|c|}{ Seed rate } \\
\hline 5 & 50.44 & 96.00 & 3.10 & $2.71^{\mathrm{a}}$ & $41.48^{b c}$ & $157^{a}$ & 65 & 78.75 & 16.48 \\
\hline 10 & 50.55 & 95.83 & 2.16 & $1.77^{\mathrm{b}}$ & $41.12^{b c}$ & $155^{\mathrm{ab}}$ & 69 & 77.00 & 17.03 \\
\hline 15 & 50.50 & 96.11 & 2.52 & $2.12^{\mathrm{ab}}$ & $42.00^{a}$ & $154^{\mathrm{ab}}$ & 65 & 79.00 & 18.11 \\
\hline 20 & 50.66 & 96.05 & 2.57 & $2.24^{\mathrm{ab}}$ & $39.00^{c}$ & $148^{\mathrm{b}}$ & 63 & 75.03 & 16.78 \\
\hline 25 & 50.43 & 96.06 & 2.45 & $2.05^{\mathrm{ab}}$ & $41.00^{\mathrm{bc}}$ & $158^{a}$ & 66 & 81.41 & 16.58 \\
\hline Local control & 50.16 & 95.83 & 1.92 & $1.53^{\mathrm{b}}$ & $41.00^{\mathrm{ab}}$ & $156^{\mathrm{ab}}$ & 69 & 86.44 & 18.28 \\
\hline Duncal at $5 \%$ & NS & NS & NS & * & * & $*$ & NS & NS & NS \\
\hline
\end{tabular}

Where, $\mathrm{DH}=$ Days to heading, $\mathrm{DM}=$ Days to maturity, $\mathrm{PH}=$ Plant height, NT=Number of tillers per plant, NET ,Number of effective tiller HL=Head length BMY= Bio-mass, and , GY=Grain yield. And NS, Non significance, ${ }^{*}$ statistically Significant and ${ }^{* *}$ statistically Highly significance.

Effects on plant agronomical parameters

The result indicated that there was no significance difference ( $p$ $>0.05$ ) on the parameters of days to maturity, number of tillers, number of effective tillers and plant height by the main effects of seeding rate and inter row spacing as well as their interaction for the year 2013 and 2014 except lodging percentage and days to heading in 2013 and number of tilers in 2014 cropping seasons at Lalibela (Table 2-4). The main effects of inter row spacing had significance effect $(p<0.05)$ on days to heading at Lalibela location for the year 2013 cropping seasons. The heights days to heading was recorded from $15 \mathrm{~cm}$ inter row spacing whereas all other treatments at par for the year 2013 cropping seasons. Seeding rate showed significance effect on lodging percentage in 2013 cropping seasons at Lalibela location. The heights lodging was recorded from $10 \mathrm{~kg} / \mathrm{ha}$ seeding rates at Lalibela location in 2013 cropping seasons whereas other treatments did not show significance difference. At Lalibela seeding rate had no significance effect in all parameters except number of tillers in 2014 cropping season. The current result did not agree with Wubante and Menzir (2017), who found that plant height, number of tillers and effective tilers and lodging percentage was affected by both the main effects of inter row spacing and its interaction with seeding rates and similarly, when the seed rate increases from $5 \mathrm{~kg} / \mathrm{ha}$ to $25 \mathrm{~kg} / \mathrm{ha}$ the lodging percentages also increases dramatically (Tesfahunegn et al., 2015). 
Effects of seedling rate

The combined analysis of seeding rate by location for the year 2014 cropping season showed significance difference for the parameters of number of effective tillers, biomass yield and grain yield. The heights grain yield was recorded from $15 \mathrm{~kg} /$ ha seeding rate $(1741.5 \mathrm{~kg} / \mathrm{ha}), 20 \mathrm{~kg} / \mathrm{ha}$ seeding rate gave $1581.9 \mathrm{~kg} / \mathrm{ha}$ and $10 \mathrm{~kg} / \mathrm{ha}$ seeding rate gave $1558 \mathrm{~kg} / \mathrm{ha}$ with no significance difference between these treatments. The lowest grain yield was recorded from $5 \mathrm{~kg} / \mathrm{ha}$ seeding rate $(1405 \mathrm{~kg} / \mathrm{ha})$ and broad casting sowing methods (1480kg/ha). Based on the combined analysis of 2014 cropping season of two location the heights biomass yield was recorded from broad casting sowing methods and the lowest biomass yield was recorded from $20 \mathrm{~kg} /$ ha seeding rates.

The combined analysis of the main effect of inter row spacing by locations for the year 2014 cropping season did not show significantly different all the parameters except days to heading the lowest days to heading was recorded from $20 \mathrm{~cm}$ inter row spacing. Even through, the treatments had no significance difference on grain yield the heights grain yield was recorded from $20 \mathrm{~cm}$ inter row spacing $(1620 \mathrm{~kg} / \mathrm{ha})$ and the lowest grain yield was recorded from broad casting sowing methods.
The combined analysis of seeding rate by inter row spacing of tef for the year 2013 and 2014 cropping seasons showed significance difference $(P<0.05)$ for the parameter of days to heading in case of main effect of inter row spacing at Lalibela (Table 5). The combined analysis for the year 2013 and 2014 cropping season at Lalibela did not show significance difference for the parameters of days to maturity, number of tillers, number of effective tillers, panicle length, plant height, lodging percentage, biomass yield and grain yield in case of main effect of inter row spacing, seeding rate and with their interactions (Tesfahunegn et al., 2015; Cheng et al., 2017).

\section{Partial budget analysis}

In this experiment, the costs for the seed rate was considered as variable cost where as other costs were constant for each treatment (Table 6). In order to recommend the present finding in the study area, it was necessary to estimate the net benefit. Based on partial budget analysis independently an interaction of, $15 \mathrm{~kg}$ ha- ${ }^{1}$ seed rate with $20 \mathrm{~cm}$ row spacing were the highest net benefit (44995) Ethiopian birr as compared to the treatment combination of maximum seed rate with that of broadcasting (40362.50) Ethiopian birr (Abraha et al., 2017).

Table 5. Grain yield and other agronomic parameters of tef as affected by seeding rate and inter row spacing combined by location by year 2013-2014.

\begin{tabular}{|c|c|c|c|c|c|c|c|c|c|}
\hline \multirow{2}{*}{ Factor } & \multicolumn{9}{|c|}{ Parameter } \\
\hline & DAH & DAM & NT & NET & LP & $\mathrm{PH}$ & LDG & $\mathrm{BM}(\mathrm{Q} \mathrm{t})$ & G.Y(Qt) \\
\hline \multicolumn{10}{|c|}{ Row spacing } \\
\hline 15 & $53.46^{\mathrm{a}}$ & 89.43 & 4.34 & 3.76 & 21.4 & 58.77 & 58.5 & 73.48 & 15.93 \\
\hline 20 & $52.73^{\mathrm{b}}$ & 89.6 & 4.16 & 3.63 & 22 & 60.80 & 55.86 & 71.49 & 16.20 \\
\hline 25 & $52.76^{\mathrm{b}}$ & 89.10 & 4.39 & 3.83 & 21.24 & 59.92 & 58.83 & 71.26 & 14.20 \\
\hline Local control & $52.66^{\mathrm{b}}$ & 88.33 & 3.50 & 2.83 & 23.83 & 58.36 & 64.83 & 80.44 & 14.80 \\
\hline Means & 52.96 & 89.23 & 4.25 & 3.68 & 21.41 & 59.59 & 58 & 72.60 & 15.40 \\
\hline $\mathrm{CV}$ & 10.77 & 2.62 & 8.9 & 11.79 & 11.79 & 9 & 10.97 & 10 & 22.58 \\
\hline Duncan at $5 \%$ & * & NS & NS & NS & NS & NS & NS & NS & NS \\
\hline \multicolumn{10}{|c|}{ Seed rate } \\
\hline 5 & 53.00 & 89.55 & 4.67 & 4.12 & 23.83 & 61.78 & 56.83 & $72.22^{b c}$ & $14.05^{b}$ \\
\hline 10 & 52.66 & 89.33 & 3.96 & 3.44 & 21.60 & 60.00 & 61.94 & $70.33^{c}$ & $15.58^{\mathrm{ab}}$ \\
\hline 15 & 52.83 & 89 & 4.15 & 3.51 & 22.41 & 5800 & 56.83 & $72.40^{\mathrm{bc}}$ & $17.41^{\mathrm{a}}$ \\
\hline 20 & 53.11 & 89.77 & 4.68 & 4.06 & 20.97 & 58.46 & 52.77 & $6792.6^{\mathrm{c}}$ & $15.81^{\mathrm{ab}}$ \\
\hline 25 & 53.00 & 88.83 & 4.01 & 3.57 & 21.06 & 56.78 & 60.72 & $77.51^{\mathrm{ab}}$ & $14.35^{\mathrm{ab}}$ \\
\hline Local control & 52.66 & 88.33 & 3.50 & 2.83 & 23.83 & 56 & 64.83 & $80.44^{a}$ & $14.80^{\mathrm{b}}$ \\
\hline Duncal at $5 \%$ & NS & NS & NS & $*$ & NS & NS & NS & * & * \\
\hline
\end{tabular}

Where, $\mathrm{DH}=$ Days to heading, $\mathrm{DM}=$ Days to maturity, $\mathrm{PH}=$ Plant height, $\mathrm{NT}=$ Number of tillers per plant, NET ,Number of effective tiller HL=Head length BMY= Bio-mass, and , GY=Grain yield. And NS, Non significance, ${ }^{*}$ statistically Significant and ${ }^{* *}$ statistically Highly significance.

Table 6. Partial budget analysis of tef as influenced by seed rate based on the combined analysis at Lalibela and Woleh locations in 2013 / 2014 cropping season.

\begin{tabular}{|c|c|c|c|c|c|c|c|c|c|}
\hline Seedling Rate & Inter row & G.Y(Qt) & UP Qt-1 & UC/K.g & TVC & SY(Qt) & UP Qt-1 (Shekim) & GB & NB \\
\hline 5 & 15 & 13.30 & 1550 & 15.50 & 77.50 & 49.14 & 200 & 30443.00 & 30365.50 \\
\hline 10 & 15 & 15.40 & 1550 & 15.50 & 155.00 & 62.74 & 200 & 36418.00 & 36263.00 \\
\hline 15 & 15 & 16.73 & 1550 & 15.50 & 232.50 & 68.14 & 200 & 39559.50 & 39327.00 \\
\hline 20 & 15 & 15.88 & 1550 & 15.50 & 310.00 & 66.59 & 200 & 37932.00 & 37622.00 \\
\hline 25 & 15 & 14.57 & 1550 & 15.50 & 387.50 & 67.63 & 200 & 36109.50 & 35722.00 \\
\hline 5 & 20 & 15.34 & 1550 & 15.50 & 77.50 & 62.29 & 200 & 36235.00 & 36157.50 \\
\hline 10 & 20 & 15.11 & 1550 & 15.50 & 155.00 & 69.18 & 200 & 37256.50 & 37101.50 \\
\hline 15 & 20 & 19.65 & 1550 & 15.50 & 232.50 & 73.85 & 200 & 45227.50 & 44995.00 \\
\hline 20 & 20 & 17.10 & 1550 & 15.50 & 310.00 & 77.33 & 200 & 41971.00 & 41661.00 \\
\hline 25 & 20 & 16.65 & 1550 & 15.50 & 387.50 & 83.33 & 200 & 42473.50 & 42086.00 \\
\hline 5 & 25 & 15.17 & 1550 & 15.50 & 77.50 & 85.63 & 200 & 40639.50 & 40562.00 \\
\hline 10 & 25 & 16.02 & 1550 & 15.50 & 155.00 & 89.11 & 200 & 42653.00 & 42498.00 \\
\hline 15 & 25 & 15.20 & 1550 & 15.50 & 232.50 & 95.25 & 200 & 42610.00 & 42377.50 \\
\hline 20 & 25 & 14.68 & 1550 & 15.50 & 310.00 & 95.25 & 200 & 41804.00 & 41494.00 \\
\hline 25 & 25 & 14.68 & 1550 & 15.50 & 387.50 & 95.25 & 200 & 41804.00 & 41416.50 \\
\hline Broad cast & & 14.00 & 1550 & 15.50 & 387.50 & 95.25 & 200 & 40750.00 & 40362.50 \\
\hline
\end{tabular}

Up =Unit Price, UC = Unit cost, TVC = Total variable cost, SY= straw Yield, GB= Gross Benefit, NB= Net benefit. 


\section{Conclusion}

In this study it was found that, seed rate and inter row spacing had significant effect on grain yield of tef at Woleh location in the year 2014 whereas, no significance difference on the grain yield of tef at Lalibela in 2013 and 2014 cropping seasons. The combined analysis of 2014 cropping season by location showed significance difference in case of seeding rates but, the combined analysis of the 2013 and 2014 cropping season at lalibela did not show significance effect in both seeding rate and inter row spacing as well as its interaction. Application of $15 \mathrm{~kg}$ seed ha-1 with $20 \mathrm{~cm}$ gave the highest grain yield and maximum biological yield. It had a net benefit of 41233 Ethiopian birr ha-1 from grain yield. Thus, it is possible to recommend that, sowing of tef with the rate of $15 \mathrm{~kg}$ ha-1and $20 \mathrm{~cm}$ inter row spacing is effective in attaining higher grain yield and economic benefit in the study area.

Open Access: This is an open access article distributed under the terms of the Creative Commons Attribution 4.0 License, which permits unrestricted use, distribution, and reproduction in any medium, provided the original author(s) if the sources are credited.

\section{REFERENCES}

Abraha, M.T., Shimelis, H., Laing, M. and Assefa, K. (2017). Achievements and gaps in tef productivity improvement practices in the marginal areas of Northern Ethiopia: implications for future research directions. International Journal of Agricultural Sustainability, 15(1): 42-53, https://doi.org/10.1080/14735903.2016.1173990

Assefa, K., Chanyalew, S. and Tadele, Z. (2017). Tef, Eragrostis tef (Zucc.) Trotter. Millets and Sorghum, In: Biology and Genetic Improvement, pp. 226-266.

Baloch, A.W., Soomro, A.M., Javed, M.A., Ahmed, M., Bughio, H.R., Bughio, M.S. and Mastoi, N.N. (2002). Optimum plant density for high yield in rice (Oryza sativa L.). Asian Journal of Plant Science, 1(1): 25-27.

Bekalu, A. and Arega, A. (2016). Effect of Seed Rate on Yield and Yield Components of Tef (Eragrostic tef Trotter) at Shebedino, Southern Ethiopia Journal of Natural Sciences Research, 6(21): 1-11.

Cheng, A., Mayes, S., Dalle, G., Demissew, S. and Massawe, F. (2017). Diversifying crops for food and nutrition security-a case of teff. Biological Reviews, 92(1): 188-198, https://doi.org/10.1111/brv.12225

CIMMYT (1988). An Economic Training Manual: from agronomic data recordation. (International Maize and Wheat Improvement center) CYMMT: Components of tef [Eragrostis tef (Zucc.) Trotter]. Mexico. Haramaya University, pp. 79.

CSA (2016). Report on area and production of crops: Central Statistical Agency. Statistical Bulletin, Volume I: 532, Addis Ababa.
Debebe, A. (2005) Performance of F4 progenies and Association amongyield and yield related traits in tef (Eragrostis tef (Zucc) Trotter). Alemaya University, Ethiopia.

Getahun, D., Tigist, A. and Adise, D. (2018). Influence of Seed Rate and Row Spacing on Growth and Yield of Tef (Eragrostis tef) Production at Assosa, Benishangul-Gumuz Regional State, Western Ethiopia (Doctoral dissertation). pp. 34.

Hailu, T., Seyfu, K. (2001). Production and Importance of Tef in Ethiopia Agriculture. In: Tef Research and Development. Proceedings of the International Workshop on Tef Genetics and Improvement, DebreZeit, Ethiopia, Haramaya, Ethiopia, pp. 3-7.

Hundera, F., Bogale, T., Tefera, H., Assefa, K. and Kefyalew, T. (2001). Agronomy research in tef.: Narrowing the Rift. Tef Research and Development. Proceedings of the International Workshop on Tef Genetics and Improvement, Debre Zeit, Ethiopia, pp: 167-176.

Ketema, S. (1997). Tef (Eragrostis tef) promoting the conservation and use of under utilized and neglected crops. Biodiversity Institute, Addis Ababa, Ethiopa. pp. 24.

Melaku, M. (2008). Effects of seeding and nitrogen rates on yield and yield components of tef Haramaya University, Haramaya, Ethiopia, (Doctoral dissertation). pp. 34.

Minten, B., Seneshaw, T., Ermias, E. and Tadesse, K. (2013). Ethiopia's Value Chains on the Move: The Case of Tef. Ethiopian Strategic Support Program, Working Paper 52. Addis Ababa, Ethiopia.

Paff, K. and Asseng, S. (2018). A review of tef physiology for developing a tef crop model. European Journal of Agronomy, 94: 54-66, https://doi.org/10.1016/j.eja.2018.01.008

Tesfahun, W. (2018). Tef Yield Response to NPS Fertilizer and Methods of Sowing in East Shewa, Ethiopia. Journal of Agricultural Sciences, 13(2): 162-173.

Tesfahunegn, G.B. (2015). Short-term effects of tillage practices on soil properties under Tef [Eragrostis tef (Zucc. Trotter)] crop in northern Ethiopia. Agricultural Water Management, 148: 241-249, https://doi.org/10.1016/j.agwat.2014.10.004

Tesfay, T. and Gebresamuel, G. (2016). Agronomic and economic evaluations of compound fertilizer applications under different planting methods and seed rates of tef [Eragrostis tef (Zucc.) Trotter] in northern Ethiopia. Journal of Drylands, 6(1): 409-422.

Tsegay, A., Vanuytrecht, E., Abrha, B., Deckers, J., Gebrehiwot, K. and Raes, D. (2015). Sowing and irrigation strategies for improving rainfed tef (Eragrostis tef (Zucc.) Trotter) production in the water scarce Tigray region, Ethiopia. Agricultural Water Management, 150: 81-91. https://doi.org/10.1016/j.agwat.2014.11.014

Wubante, N. and Menzir, M.K. (2017). Effect of Row Spacing on Yield and Yield Components of Teff [Eragrostis tef (Zucc.) Trotter] Varieties in Gonji Kolela District, North Western Ethiopia. Journal of Biology, Agriculture and Healthcare, 7(23): 1-11. 